\title{
Informal, Non-formal, and Formal Networking: Ensuring Autonomy and Flexibility for Special Needs Coordinators
}

New Zealand Journal of Teachers' Work, Volume 14, Issue 2, 114-135, 2017

\author{
ALISON KEARNEY \\ MANDIA MENTIS \\ WENDY HOLLEY-BOEN \\ Institute of Education \\ Massey University
}

\begin{abstract}
The importance of the Special Needs Coordinator (SENCO) in facilitating inclusive and equitable education is well supported in the literature with many countries formalising the role through legislation and policy. New Zealand however, while adopting the role of SENCO, has not formalised this role, meaning that those in SENCO positions in New Zealand experience high levels of flexibility and autonomy. This article reports on a study of New Zealand SENCOs, highlighting their day-to-day work. A model of networked SENCO expertise is presented that reinforces SENCO autonomy and flexibility while also facilitating their needs for collaboration, sharing of practice and ongoing professional learning.
\end{abstract}

\section{INTRODUCTION}

With the growing international trend towards the creation of equitable and inclusive education systems, the role of the Special Education Needs Coordinator (SENCO) in schools has been widely adopted throughout the world. The title and role of the SENCO originated from the British Education system (Collinson, 2011) where it was mandated in the 1994 Code of Practice on the Identification and Assessment of Special Educational Needs (DfE, 1994). This code placed a legal obligation on all schools to identify a specialist teacher who would act as a coordinator of special education provisions within a school. This code also provided information on the nature of the SENCO role including the specific responsibilities of that person. In describing the role, emphasis was placed on SENCOs engaging in strategy development and the operation of special education needs policy and provision as well as supporting the head teacher and other colleagues to identify and overcome barriers to learning for children with special education needs. It was not intended that the SENCO would take sole responsibility for individual children with special educational needs, but rather take on a managerial role within the school, supporting and collaborating to bring about more equitable outcomes for learners identified as 
having special educational needs (Mackenzie, 2007). This Code was revised in 2014 (DfE/DoH, 2014) with a requirement for SENCOs to manage change and facilitate inclusive school cultures (Done, Murphy \& Bedford, 2016).

In New Zealand, the role of the SENCO was first proposed in the Wylie Report (Wylie, 2000), which reviewed special education in New Zealand at that time. In this report, Wylie recommended the establishment of a Special Education Needs Coordinator in every school. She highlighted the potential of this role to boost the capacity of schools by delivering professional development and support to teachers and by providing a person who could act as a conduit between the school and those other professionals and agencies who could support students with special education needs and their teachers. Although many New Zealand schools have created a SENCO role, Wylie's recommendation has never been officially adopted. There is no legal obligation on schools in New Zealand to appoint a SENCO and no formal recognition of this role by the New Zealand Ministry of Education. Schools do not receive any management units, additional staffing entitlements or funding to support the SENCO position (NZEI, ${ }^{1}$ 2016) and there is no requirement for any formal additional training or qualification to become a SENCO. Not only is this lack of formal support and recognition of the SENCO role contrary to the recommendation of the Wylie report, it also flies in the face of international literature and key New Zealand Government agency reports which highlight the power of the SENCO role in enabling the development of inclusive and equitable schools.

New Zealand has a long history of promoting, through educational initiatives and policies, the principles and practices of inclusive education. Inclusive education, which is situated within theories of equity and social justice, involves increasing the presence, participation and learning of all students, but particularly those students who have historically been excluded or marginalised both from and within school (Booth \& Ainscow, 2011). In 1996, a policy Special Education 2000 - was introduced in New Zealand that aimed to create a world-class inclusive education system by the year 2000 (Ministry of Education, 1996). Since that time, a range of educational policies and initiatives have been implemented. Additionally, 'inclusion' is one of the key principles underpinning the New Zealand Curriculum, and there is legislation in place to protect the rights of all children to attend their local school and have their needs met without discrimination.

Equity and social justice remain elusive in New Zealand schools despite these initiatives and policies that aim to support and promote inclusive education. Students still experience exclusion from and within school on the basis of personal and social factors such as gender, ability, ethnicity, social class, sexuality and mental health status (New Zealand Human Rights Commission, 2010). There are a number of factors that contribute to this exclusion including:

1 NZEI is a New Zealand Union representing predominantly primary school teachers and professionals It should be noted that the union representing predominantly secondary school teachers and professionals is the NZPPTA. SENCOs in New Zealand can belong to either. 
- the resilience of deficising and pathologising paradigms (Berryman, 2014; Slee, 2011);

- power imbalances, particularly between parents/whānau ${ }^{2}$ and schools (Kearney, 2014) and between Māori, Pasifika and Pākehā (Slee, 2011);

- the silencing of student voice (New Zealand Youth Law, 2012);

- systems of competition between schools (Wills \& Rosenbaum, 2014); and

- the lack of recognition of disadvantage and injustice (Slee, 2011).

Also contributing to the elusive nature of inclusive education is the contestability of the term. While inclusive education grew out of human rights imperatives and theories of equity and social justice, it has been adopted by competing paradigms and used as a guise for continuing practices of exclusion (Slee, 2011). In particular, special education paradigms that identify difference as requiring remediation is one such area where this has occurred (Kearney, 2011).

Despite these tensions, national and international studies highlight the potential of the SENCO role for facilitating inclusive school communities. For example Cole (2005) found that SENCOs played a significant role in the development of inclusive schools, particularly for students with disabilities. This included providing professional development to staff, networking with professionals, setting school policy and organisational procedures and supporting curriculum development. Studies have also shown that SENCOs have the potential to engage parents (Burton \& Goodman, 2011; Collinson, 2011), influence the development of policies that support inclusive practices (DfE, 2004, Rayner, 2007), support teachers in the implementation of inclusive practices (Winwood, 2016), improve communication between schools and their Boards of Trustees (Collinson, 2011), engage with students and their specific needs (Burton \& Goodman, 2011) and develop school capacity so as to rely less on external support agencies (Taylor, 2014).

Similar support for the role that SENCOs can play as agents of inclusion has been reported by the New Zealand Education Review Office (ERO) when they investigated the inclusiveness of New Zealand schools. In three reports that were published in 2010, 2013 and 2015, the importance of the SENCO role in contributing to the development of inclusive schools was identified. In the 2010 report, the importance of the leadership role of SENCO for supporting students with high needs was highlighted with ERO reporting that:

one of the most important roles requiring an experienced and able leader is that of SENCO. The SENCOs role is pivotal for ensuring that students with high needs have the

\footnotetext{
${ }^{2}$ Maori are the indigeneous peoples of New Zealand. Whānau is the Maori word for family.
} 
learning programs and support they need to achieve at school (Education Review Office, 2010, p.13).

In the 2013 report, ERO highlighted that many of the schools identified as 'mostly inclusive' had a SENCO with experience and appropriate training and that this was critically important in promoting a "cohesive and school wide approach to inclusion" (Education Review Office, 2013, p.7). The 2015 ERO report found that most schools that were identified as inclusive had SENCOs who contributed to the strategic plans of the school, coordinated the involvement of families, specialist services and Individual Education Plans (IEPs), provided professional development, coordinated support and resources, identified students requiring extra support and documented and monitored their progress (Education Review Office, 2015).

Given the nature and extent of support for the role of SENCO, particularly in the creation of inclusive and equitable education systems, the lack of official recognition of this role in New Zealand is puzzling. With no policy, mandate or guidelines for the use of SENCOs in New Zealand schools and little research into the SENCO role, there is limited information about how this role has manifested itself in schools, including the nature and extent of SENCO practice and the beliefs and practices of those teachers that fulfil this role. A study, reported in this article, sought to address this gap in the literature.

\section{METHODOLOGY}

In 2016, the authors were involved in providing a blended (online and face-to-face) professional learning course to 75 SENCOs in New Zealand. Participants were initially recruited to the course through online advertising via an email to every school in New Zealand. At the beginning of the course, participants were invited to participate in an anonymous online questionnaire that investigated the role of SENCO within New Zealand schools-65 participants choose to complete this questionnaire. Participants in the study were working as SENCOs in all levels of the compulsory education sector. The questionnaire consisted of 20 questions, 10 of which were qualitative and 10 quantitative. Along with demographic information, participants were asked to describe their understandings of the SENCO role, the type of tasks they carried out, their levels of confidence, competence and satisfaction in relation to the role, and any professional development/induction they had received. Participants were also asked about the barriers and enablers to carrying out the role.

Basic quantitative analysis measures were employed to analyse the quantitative data, mostly prevalence figures. In relation to the qualitative data, a thematic analysis method was used. This involved a sequential process of familiarisation with the data, coding to identify important features of participants responses, searching for broader themes across the coding, then defining the themes (Braun \& Clarke, 2006).

\section{RESULTS}

Respondents had a range of experience in the role of SENCO with $38 \%$ having been in the role less than two years, $25 \%$ between three and five years, 
$23 \%$ six to ten years and $14 \%$ had been in the SENCO role for more than ten years. The majority of respondents were working in a primary school $(64 \%)$ with $6 \%$ working in intermediate schools, $22 \%$ in secondary schools and $8 \%$ in other types of schools (for instance special schools). Schools ranged in size from those with less than 50 students to those with more than 600 .

\section{The Nature of the SENCO Role}

SENCOs were asked to describe their role in a few words. The most common theme to emerge from their descriptions was 'being a coordinator' (38\%). Respondents explained this as being involved in a range of activities such as the provision of programmes and support, coordinating learning support referrals, liaising with outside agencies and parents, overseeing the provision of Teacher Aides and the development and implementation of individual education plans. This coordination role is evident in the following participant response:

In my role as Special Needs Coordinator, I am responsible for looking after all students requiring additional support. Included in this I coordinate additional learning programmes for students with specific needs, make referrals...coordinate IEPs and liaise with agencies, liaise closely and regularly with the parents of these students, look after all the Teacher Aides...and coordinate their timetables. (Respondent 62)

Other respondents described their role as one of a support person (22\%), which involved supporting students and teachers in order to raise students' outcomes and achievement. The complexity of this advocacy role is outlined in the following participant response:

Coordinating support for students with special education needs in the school includes referrals, liaison with outside agencies, Teacher Aide timetabling and support, reporting to the Board of Trustees ${ }^{3}$, maintaining knowledge about special education systems, resources and effective practices within wider New Zealand education system. (Respondent 38)

Acting as an advocate for students was identified by $14 \%$ of respondents. Here SENCOs described working for the best interests of the students as illustrated in the following response:

It involves being an advocate for all students. (Respondent 35)

\footnotetext{
3 New Zealand schools are governed by Boards of Trustees, which are made up of the school principal and elected members.
} 
Other respondents described their role as an interprofessional change agent to bring about positive outcomes as the following respondent illustrates:

(My role is a) co-coordinator or catalyst that causes change for a student ensuring they can achieve to the best of their potential. Change involves student, family, internal support and external agencies to work together. (Respondent 65)

SENCOs were asked to think about a typical week and indicate how they spent their time. They were given a list of tasks reported in the literature to make up the work of SENCO. Results as outlined in Table One showed the varied nature of the SENCO role in that not one task could be seen to dominate their work. There were some tasks, however, that made up quite large proportion of their role, and this was the case for many of the respondents. For example, most SENCOs reported that working on administration tasks, such as report writing and funding applications, was their predominant task. For $53 \%$ of respondents, this took up approximately a quarter of their time and for $20 \%$ of respondents, this accounted for half of their time, followed by attending meetings and working with Teacher Aides. Working with the whole staff, engaging in ongoing professional learning and working with parents were the least predominant tasks carried out by respondents.

All respondents held other roles within their school alongside their SENCO role. These included being a school principal or deputy principal (23\%), class teacher (45\%) and Ongoing Resourcing Scheme (ORS) Teacher (for learners with very high needs) (26\%). As well as this, respondents indicated other management or leadership roles that they held within the school including sports coordinator, leader of department/syndicate/team, gifted and talented coordinator, Reading Recovery Teacher and English Speakers of Other Languages (ESOL) Teacher.

\section{SENCO Preparedness and Confidence}

When asked about any induction or mentoring they had received in preparation for the SENCO role, $52 \%$ of respondents indicated that they had received none and $20 \%$ indicated that they had received very little. For the minority who had received either mentoring or induction, this was provided in the form of support from the outgoing or previous SENCO, or from other SENCOs that were known to them. Resource Teachers of Learning and Behaviour (RTLB) ${ }^{4}$ were also identified as providing some support and induction into the role. Three respondents had a meeting or discussion with the school principal or deputy principal. The paucity of any formal induction into the role is evident in the following responses from participants in response to whether they received support when taking up the SENCO position:

\footnotetext{
${ }^{4}$ A RTLB is a specialist teacher who works with class teachers and schools to meet the needs of students within an inclusive education system.
} 
Very little. Spend some time (approx. two hours) with the previous SENCO. (Respondent 16)

A few chats with the new principal in how she wanted things set up. (Respondent 18)

None. I was asked if I wanted to do it as the previous SENCO left...very much learning on the job. (respondent 48)

When asked about the manageability of the SENCO role, $5 \%$ reported that it was very manageable, $55 \%$ as manageable, $29 \%$ as slightly unmanageable and $9 \%$ as unmanageable. In relation to their confidence to carry out the role, $11 \%$ felt very confident, $56 \%$ confident, $25 \%$ neither confident nor unconfident and $8 \%$ unconfident.

\section{Professional Development and Learning}

SENCO respondents were asked what professional development and learning they had received since beginning their SENCO role. All had been involved in some form of professional development and learning. For most, this had been in the nature of one-day courses on a wide range of topics that seemed to be tailored to each SENCO's individual needs and the needs of their school. Common topics included communication, learning, behaviour and health areas. The type of formal professional learning is indicated in the following response:
I have attended various seminars...one-day workshops, ESOL workshops...conferences and workshops. (Respondent 27)

The next most common type of professional learning and development that respondents had engaged in were various support networks within the education communities that they operated within, predominantly regional SENCO networks many of which were facilitated by the RTLB service. These non-formal networks were positively received as evident in the following response:

Once a term I meet with a group of SENCO teachers in the [name of region] - brilliant! (Respondent 7) 


\begin{tabular}{|c|c|c|c|c|c|c|c|}
\hline & Never & $\begin{array}{l}\text { Less } \\
\text { than } \\
10 \%\end{array}$ & $\begin{array}{c}\text { About } \\
25 \%\end{array}$ & $\begin{array}{l}\text { About } \\
50 \%\end{array}$ & $\begin{array}{c}\text { About } \\
75 \%\end{array}$ & $\begin{array}{c}90- \\
100 \%\end{array}$ & $\begin{array}{c}\text { Not } \\
\text { answered }\end{array}$ \\
\hline $\begin{array}{l}\text { Working with } \\
\text { individual children }\end{array}$ & 6 & 37 & 11 & 6 & 4 & 1 & 0 \\
\hline Working with parents & 2 & 51 & 10 & 2 & 1 & 0 & 0 \\
\hline $\begin{array}{l}\text { Working with } \\
\text { individual teachers }\end{array}$ & 5 & 43 & 14 & 2 & 2 & 0 & 0 \\
\hline $\begin{array}{l}\text { working with the full } \\
\text { school staff }\end{array}$ & 14 & 46 & 4 & 0 & 0 & 0 & 1 \\
\hline $\begin{array}{l}\text { Working with with } \\
\text { Teacher Aides }\end{array}$ & 3 & 34 & 17 & 5 & 5 & 1 & 1 \\
\hline $\begin{array}{l}\text { Working with with } \\
\text { management }\end{array}$ & 3 & 42 & 13 & 3 & 3 & 1 & 0 \\
\hline $\begin{array}{l}\text { Working with with } \\
\text { other professionals } \\
\text { (e.g. psychologists, } \\
\text { speech language } \\
\text { therapists etc) }\end{array}$ & 2 & 38 & 19 & 4 & 2 & 0 & 0 \\
\hline $\begin{array}{l}\text { Ongoing professional } \\
\text { learning }\end{array}$ & 5 & 52 & 6 & 2 & 0 & 0 & 0 \\
\hline $\begin{array}{lr}\text { Working } & \text { on } \\
\text { administration } & \text { tasks } \\
\text { (e.g. } & \text { funding } \\
\text { applications, report } \\
\text { writing) }\end{array}$ & 3 & 8 & 35 & 13 & 5 & 1 & 0 \\
\hline $\begin{array}{l}\text { Attending meetings } \\
\text { (e.g. IEP) }\end{array}$ & 1 & 37 & 19 & 6 & 1 & 2 & 0 \\
\hline Other & 2 & 20 & 0 & 2 & 1 & & 0 \\
\hline
\end{tabular}

Table 1: How do SENCOs Spend Their Time in a Typical Week? $(n=62)$

While most respondents considered the notion of professional development and learning from a traditional formal perspective, where experts deliver content, some respondents highlighted the more non- formal and informal aspects to their professional development and learning as the following responses indicate: 
I work closely with our Resource Teacher of Learning and Behaviour (RTLB) and lead Ministry of Education worker. (Respondent 63)

[Name of support person] has seen me once a fortnight since beginning this role in February. Her help has been outstanding. (Respondent 58)

Most of my professional development now comes from Twitter and RSS feeds of blogs. (Respondent 21)

Most of the SENCO respondents had been involved in the provision of professional learning to staff in their school $(88 \%)$. Predominantly this was to Teacher Aides, but providing school-wide professional learning to school staff members was also a common form of professional learning provided by SENCO. Lesser forms included specific workshops, informal conversations, modelling and mentoring.

\section{SENCO Satisfaction with the Role}

When asked to indicate how fulfilling they found the SENCO role, nearly all respondents reported it either very fulfilling $(48 \%)$ or fulfilling $(43 \%)$. Only $8 \%$ of respondents reported that the role was slightly unfulfilling (one person did not respond to this question). When asked to identify the top three 'positive' aspects of their role, the predominant theme to emerge was the potential to make a difference for students and to see them succeed, for example:

Making a difference-sometimes large changes and sometimes little small things. (Respondent 55)

Seeing the change in the children I support. (Respondent 49)

Making a difference by working together with students, whanau and agencies to set up supports that will make a positive difference for students. (Respondent 46)

Working with others as part of a team was the next most common theme to emerge from the top three. This included working with other teachers, outside agencies, parents and the students themselves. The value of collaboration is evidenced in the following responses of the top three positive aspects of the role:

Working with staff who are determined to provide quality education for their students. Seeing students succeeding who would not have without support we accessed. Working with whānau. (Respondent 62)

Interaction with students Interaction with parents/outside agencies. Autonomy, scope to problem-solve. (Respondent 26) 
The variety, challenge and ongoing learning that is part of the role was the third most common theme of respondents top three positive aspects of the role:

Not knowing what to expect on any given day-every day is different. (Respondent 4)

Respondents also reported pressures associated with the role, however, and when asked to identify the top three pressures, the greatest pressure was lack of time, followed by lack of resources and/or funding, dealing with outside agencies and the amount of paperwork that was required. The effects of being time-poor with limited resources is evident in the following concerns raised by respondents:

Trying to keep so many balls in the air and worrying that ultimately a really important one will drop. 2. Lack of sufficient money/resources allocated to children that need help. 3. Frustration with 'the system', especially RTLB referral systems, and the slow pace of attention given to what I consider to be high priority needs. (Respondent 12)

Ensuring that everyone involved with the student is 'on the same page', especially those with behavioural issues where consistency is required. Accessing the external support in a timely manner for the needs of the student, staff and families. Time to do the job effectively. (Respondent 18)

Time pressures-there isn't enough time. Teachers expecting a TA to 'fix' an issue. Not enough money in the budget. (Respondent 51)

\section{Availability of Factors to Support Inclusive Practice in the SENCO Role}

Respondents were given a range of factors shown in the literature to support inclusive practice, and asked to indicate how available these were to them in their role. Table Two presents these findings. With the exception of manageable workloads, adequate release time, the 'mana' (status) of the role, shared understandings of their role and appropriate resourcing, SENCOs found a range of key supports available to them. The supports SENCO most identified as consistently available to them included positive partnerships with their students; leadership promoting inclusive practice and inclusive school values. 


\begin{tabular}{|l|c|c|c|c|}
\hline & Consistently & Sometimes & Never & N/A \\
\hline Positive partnerships with students & 47 & 18 & 0 & 0 \\
\hline $\begin{array}{l}\text { Leadership that promotes inclusive } \\
\text { practice }\end{array}$ & 39 & 26 & 0 & 0 \\
\hline Inclusive school values & 38 & 27 & 0 & 0 \\
\hline $\begin{array}{l}\text { Collaborative partnerships with } \\
\text { families and whānau }\end{array}$ & 35 & 30 & 0 & 0 \\
\hline $\begin{array}{l}\text { Collaborative partnerships with } \\
\text { teachers and Teacher Aides }\end{array}$ & 34 & 30 & 1 & 0 \\
\hline Inclusive school cultures & 32 & 33 & 0 & 0 \\
\hline Autonomy and influence in the role & 31 & 33 & 1 & 0 \\
\hline Inclusive school policies and practices & 31 & 34 & 0 & 0 \\
\hline Positive community relationships & 29 & 36 & 0 & 0 \\
\hline $\begin{array}{l}\text { A team approach to supporting all } \\
\text { learners }\end{array}$ & 28 & 36 & 1 & 0 \\
\hline Professional development & 26 & 39 & 0 & 0 \\
\hline Adequate release time & 24 & 32 & 5 & 3 \\
\hline The mana of the role & 19 & 41 & 2 & 3 \\
\hline $\begin{array}{l}\text { Shared understandings of the SENCO } \\
\text { role }\end{array}$ & 10 & 52 & 3 & 0 \\
\hline A manageable workload & 8 & 47 & 10 & 0 \\
\hline Appropriate resourcing & 54 & 3 & 0 \\
\hline
\end{tabular}

Table 2: Availability of factors supporting inclusive practice in the SENCO role $(n=65)$

\section{DISCUSSION}

Results of this study provide an insight into the role of the SENCO in New Zealand. Despite not having an official job description, respondents were able to clearly articulate what they believed was the purpose of their role. There was a level of consistency of responses in relation to articulating this with respondents reporting this role as the coordination of services for students who required additional help and to support them and their teachers so that they could be successful at school. A possible explanation for this consistency of understanding, despite the absence of national and official guidelines for the SENCO role, is the consistency of messages found in government policies in 
this area, particularly in relation to inclusive education. As outlined earlier in this article, reference to inclusive education can be found in the national curriculum and in a range of legislation and policy initiatives that are embedded into school policy and practice across New Zealand. It is, however, also worth noting that just as policy can influence practice, so can practice influence policy and teachers can act as policy-makers (Cuban, 2015). Teaching is an inherently political profession and the shaping and defining by SENCOs of their role in New Zealand schools does have the potential to play an important part in shaping current and future Government initiatives and policies in relation to this role. SENCOs are likely to be more successful in this regard if they recognise this influence and network with other SENCOs to bring about desired change.

An important finding of this study is that most respondents from across all levels of the compulsory sector, reported satisfaction with the manageability of the role $(60 \%$ of respondents reported it either very manageable or manageable) and most reported feeling confident to carry out the role $(67 \%$ indicating that they felt either very confident or confident) Similarly, respondents reported high levels of fulfilment in the role, with $91 \%$ finding it either very fulfilling or fulfilling. In line with SENCOs' description of their role to assist students who required additional support, when asked to identify the 'positive' aspects of their role, the main theme to emerge was the potential of the role to make a difference for students and to see them succeed. These findings are in keeping with an Organisation for Economic Co-operation and Development (OECD, 2014) study into the confidence and satisfaction of New Zealand teachers. Findings showed that $89 \%$ of New Zealand's year 7-10 teachers think the advantages of the job outweigh any disadvantages. This is in comparison to an average of $77 \%$ of teachers in the other 35 countries who were part of the research. Other findings from the New Zealand teacher participants were that $92 \%$ enjoyed working at their school and $86 \%$ thought that they could help students learn.

This finding is important as the high levels of satisfaction and confidence reported appears to be at odds with the fact that most of the respondents had taken up the SENCO role with little or no induction or training $(52 \%$ indicated that they had received no induction or training for the role, and $20 \%$ indicated that they had received very little). This finding could be linked to SENCOs reporting that they had been involved in some form of professional development and learning since taking up their roles. Given, however, that $63 \%$ of respondents had been in the SENCO role for five or fewer years, this finding of high satisfaction and confidence levels in the role with little induction or training, is worthy of further research.

Results from this study highlight the breadth and variety of the SENCO role. While there was no single task that dominated their time, the majority of respondents spent most of their time on administration tasks, followed by attending meetings and working with Teacher Aides. Contrary to the reported activities of SENCOs in the United Kingdom (e.g. DfE/DoH, 2015), supporting other school staff, particularly in relation to their professional learning, was not something that many SENCOs in this study engaged in. Similarly, it is worth noting that few SENCOs devoted time to their own professional learning, and for those that did, this was a very small proportion of their day-to-day work.

Studies show that the SENCO role has the potential to support the development of inclusive schools (e.g. Burton \& Goodman, 2011; Cole, 2005, 
Winwood, 2016), however there are a range of obstacles that can impede the agency of SENCO to facilitate inclusive practices and environments. These include:

- the belief of teachers and other educational professionals that SENCOs should work with individual students in a remediation role (Lindqvist, 2013);

- a lack of knowledge on the part of SENCOs required to carry of the role effectively;

- negative attitudes by SENCOs and other school staff towards inclusive education (Abbott, 2007); and

- limited influence, for example not being in a leadership role within the school (DfE/DoH, 2015 Oldham \& Radford, 2011).

Respondents in this study were given a range of factors shown in the literature to support inclusive practice, and asked to indicate how available these factors were to SENCOs in their role. For many respondents, positive partnerships with students, leadership that promotes inclusive practice, and inclusive school values were often available to support them in their role. Least available to them was a manageable workload and appropriate resourcing. It is likely that those factors that respondents reported as available to them were due to the desire and effort of their school to bring about positive change for students who require extra support. Problematically, factors least available to them are those that will need to be government and/or management driven. Providing SENCOs with dedicated time to carry out their role effectively along with the resources to do so seems an important first step on the part of government, and/or governing bodies even if there is no desire on their part to define and mandate the SENCO role. This will require some form of funding for release time and access to appropriate levels of resourcing.

\section{IMPLICATIONS}

This small study provides some insights into the nature of the SENCO role in New Zealand and into the beliefs and attitudes of those teachers who carry out this role. A surprising finding from the study was that despite there being no legal obligation on schools in New Zealand to appoint a SENCO, no formal recognition of the role from the New Zealand Ministry of Education, and no official training or qualification to become a SENCO, the participants reported high levels of motivation and satisfaction in relation to their role and demonstrated a strong belief in the importance of the role in making a positive difference for students who require extra support. A possible explanation for these high levels of motivation and satisfaction is that the autonomy and independence that SENCOs in New Zealand have in relation to the role, supports their sense of agency, particularly when situated within strong Government policies and initiatives focused on developing systems of inclusive education and within the structures of self-governing schools. 
Another important finding was that despite being time-poor and underresourced, SENCOs actively engaged in formal, non-formal and informal professional learning, and valued teamwork and collaboration.

Given these findings, we suggest that instead of formalising and standardising the SENCO role, which may at first appear to be an important action, it would be better to continue to support the autonomy and flexibility within the SENCO role, while also providing better structures for ongoing professional learning, collaboration and sharing of practice. This would afford SENCOs across New Zealand the opportunities to build their capability and leadership within schools.

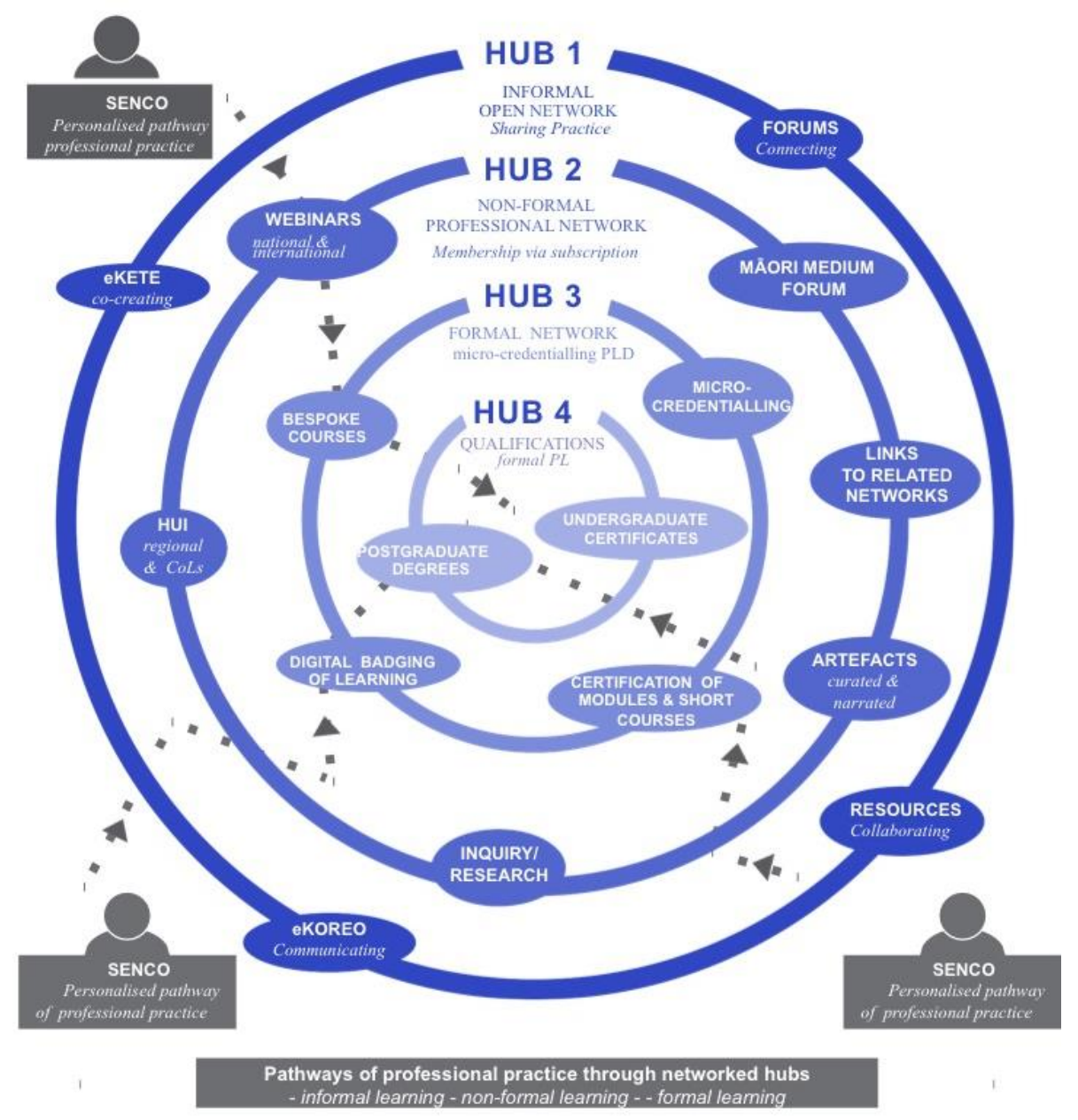

Fig. 1: Model for a network of SENCO expertise 
To this end, a model (see figure 1) for a network of SENCO expertise is being developed by the authors of this paper to enable SENCOs in New Zealand to meet their need for professional learning and collaboration, while avoiding standardising and formalising their position. The network of expertise model consists of four hubs. The outer hub will be an informal network of professional learning and practice for SENCOs across New Zealand to connect, communicate, collaborate and share practice. This hub will consist of a password-protected online site with discussion forums to facilitate conversations between SENCOs about their practice. This informal network will also provide opportunities for sharing of resources relating to SENCOs' domain of practice in the area of learning support. SENCOs will be able to co-create an online database of curated artefacts and resources. Through conversations and collaborative sharing of resources, SENCOs will have opportunities to learn with, from and about each other's practice, thus strengthening the teamwork that SENCOs reported in the study as being one of the positive aspects of their role. This hub will serve as an authentic and open online community of practice where participants can curate and evaluate resources online, to co-create a national repository of evidence-based practices. The online forums will provide a shared space to discuss the application of these practices in different contexts. A national SENCO coordinator will act as a steward for this outer hub of the networked community ${ }^{5}$.

This first hub of expertise will flow into the second hub, which aims to provide SENCOs with further opportunities for non-formal professional learning and collaboration. Membership to this hub will enable access to regular and more in-depth resources, publications and news; webinars with guest presenters; discussion forums; chat-rooms; event notifications; potential research collaborations; good practice exemplars; awards; regional and national face-to-face conferences, and further links to relevant organisations and other networks. Hub two will foreground effective practice from the field and will be coordinated by a group of regional SENCOs.

Hubs three and four will focus on more formal networks of professional learning and practice. In hub three SENCOs will have the opportunity to choose to complete short courses and bespoke modules of professional learning for micro-credentialing. The short courses and modules will be individualised and in response to identified needs. Completion of modules will be acknowledged though certification using a digital badging system. Digital badges will signify achievement through linking the badge images or symbols to meta-data on the competencies met as well as the badge issuer and date. SENCOs could display their badges on their personal websites, blogs, or digital curriculum vitaes, and the meta-data will allow for verification of badge credentials. SENCOs could potentially collect and combine these digitally badged credentials towards a formal university qualification in learning support in hub four.

Hubs three and four thus consolidate the network of expertise by providing opportunities for SENCOs to follow their own personalised learning pathway to gain formal credits, qualifications, and professional recognition in the field. SENCOs will be able to add-on and cross-credit digitally badged professional

\footnotetext{
${ }^{5}$ See here for the learning support network: https://www.thelearningsupportnetwork.org/
} 
learning modules, along with artefacts that evidence effective practice, into a formal university qualification in learning support. This will enable SENCOs to continue life-wide and life-long connected learning that is self-directed and relevant for their current context, interests and needs.

The four hubs will thus provide SENCOs with a 'place', 'space' and 'face' to network and develop expertise through connected learning and practice. SENCOs will have a 'place' to communicate and collaborate both online and offline, nationally and regionally in wider and smaller networks of practice. The online site will serve as a 'space' for a national repository of resources that SENCOs themselves co-create, curate and evaluate. Networking regionally and nationally will raise the profile and 'face' of SENCOs as they collectively debate and narrate their professional role and identity. The network of expertise will recognise and strengthen the status of SENCO while still ensuring autonomy and flexibility over what and how they engage in professional learning, practice, and define their role. The network has potential to provide evidence-based leadership in the area of learning support, raising the professional position of SENCOs throughout New Zealand and facilitating ecological and integrated learning support networks. This will create a ripple of expanding networks of increasing professionalism, capability and connectedness.

This Network of Expertise in Learning Support fits within the New Zealand Ministry of Education redesign of Professional Learning and Development (PLD) initiative. As part of this initiative the Ministry of Education is developing a plan to support and strengthen existing professional networks such as subject associations and contracted a needs analysis to be undertaken which identified enablers and barriers to networks and associations being successful. (Childs, Dryden, \& Jeffries, 2017). Relevant for this project are the findings that networks for teachers should be 'for teachers, by teachers'; that PLD needs to be "agile, responsive and timely" (Childs, Dryden, \& Jeffries, 2017, p.7) and that networks should be set up to provide relevant and current resources, examples of best practice, support in particular for single teacher subjects, be needsdriven and must include blended approach and not just online portals. These findings align closely with a model that facilitates a blurring of the boundaries of formal, non-formal and formal PLD and enables connected life-long and lifewide learning.

\section{CONCLUSION}

There is little doubt that the role of SENCO is critical in facilitating and supporting inclusive schools. Research studies, such as those as reported in this article, clearly demonstrate the potential of the SENCO to support students and teachers so that schools are places where all students can belong, participate and learn. Because of this, many countries around the world have formalised the SENCO role by way of ensuring that they are experienced and qualified, hold senior management positions and are governed by clear job descriptions that prescribe their work (for example the United Kingdom). New Zealand has, however, not followed this path, instead allowing the SENCO role to evolve in a much less formalised and prescriptive way.

This article has outlined a snapshot of the role of SENCO in New Zealand highlighting the day-to-day working of SENCOs, their feelings of preparedness, confidence and satisfaction, the supports available to them and their 
engagement in professional learning. Given the lack of formal policy or legislation defining and directing the role in New Zealand, SENCOs have potentially high levels of autonomy, flexibility and agency and it has been suggested that this may contribute to their general feelings of confidence and satisfaction in carrying out the role. The need for support, collaboration and shared principles of practice between SENCOs was, however, also acknowledged as being important, and a suggested model of networked expertise that can facilitate this has been outlined in this article.

This model of informal, non-formal and formal network of professional learning and practice has the potential to allow for the continued agency of SENCOs, but also meet their need to connect, communicate and collaborate with their SENCO colleagues throughout New Zealand. Through open and informal networking, SENCOs can engage with each other nationally in online discussions and share resources to support their practice and life-long learning. Non-formal networking provides SENCOs with the option to become members of a professional community and benefit from more structured learning and practice opportunities. At the level of formal networking, SENCOs can gain credentials for completing professional learning modules that are bespoke to their and their school's needs. These credits can contribute to gaining a formal university qualification that is also uniquely self-directed.

Given the importance of autonomy and agency for SENCO job satisfaction, the need for them to engage in lifelong learning and the importance of collaboration and sharing of good practice, this model of informal, non-formal and formal networked expertise has the potential to ensure that SENCOs in New Zealand can successfully support inclusive and equitable education throughout the country.

Manuscript Submitted: June 6, 2017

Revised Manuscript Received: August 21, 2017

Revised Manuscript Accepted: September 21, 2017 


\section{REFERENCES}

Abbott, L. (2007). Northern Ireland Special Educational Needs Coordinators creating inclusive environments: an epic struggle. European Journal of Special Needs Education, 22(4), 391-407. https://doi.org/10.1080/08856250701650003

Berryman, M. (2014). Relational and culturally responsive, indigenous approach to belonging and inclusion. In R. Wills, M. Morton, M. McLean, M.Stephenson \& R. Slee (Eds.), Tales from school. Learning disability and state education after administrative reform (pp. 199-212). Rotterdam, The Netherlands: Sense Publishers.

Booth, T., \& Ainscow, M. (2011). Index for inclusion: Developing learning and participation in schools. Bristol, United Kingdom: Centre for Studies on Inclusive $\quad$ Education. Available from http://www.eenet.org.uk/resources/docs/Index\%20English.pdf

Burton, D., \& Goodman, R. (2011). Perspectives of SENCOs and support staff in England on their roles, relationships and capacity to support inclusive practice for students with behavioural emotional and social difficulties. Pastoral Care in Education, 29(2), 133-149. https://doi.org/10.1080/02643944.2011.573492

Braun, V., \& Clarke, V. (2006). Using thematic analysis in psychology. Qualitative Research in Psychology, 3(2), 77-101. https://doi.org/10.1080/02643944.2011.573492

Childs, D., Dryden, S., \& Jeffries, T. (2017). Needs analysis. Networks of expertise. Available from http://services.education.govt.nz/assets/Uploads/Needs-AnalysisNetworks-of-Expertise.pdf

Cole, B. (2005). Mission impossible. Special education needs, inclusion and the reconceptualization of the role of the SENCO in England and Wales. European Journal of Special Needs Education, 20(3), 287-307.

Collinson, L. (2011). The developing role of the special education needs coordinator. Unpublished Masters Thesis, Victoria University Wellington, New Zealand. Available from http://researcharchive.vuw.ac.nz/xmlui/bitstream/handle/10063/1940/thes is.pdf? sequence $=1$

Cuban, L. (2015). Policy influences practice but does practice influence policy? [Webblog post]. Available at https://larrycuban.wordpress.com/2015/08/19/policy-influences-practicebut-does-practice-influence-policy/

Department for Education [DfE]. (1994). Code of Practice on the identification and assessment of Special Educational Needs. London, United Kingdom: Department of Education. Available from https://eric.ed.gov/?id=ED385033

Department for Education/Department of Health [DfE/DoH]. (2015). Special Educational Needs and Disability Code of Practice. London, United Kingdom: HMSO. Available from https://www.gov.uk/government/uploads/system/uploads/attachment dat a/file/398815/SEND Code of Practice January 2015.pdf

Done, E., Murphy, M., \& Bedford, C. (2016). Change management and the SENCO role: Developing key performance indicators of inclusivity. 
Support for Learning, 31(1), 13-26. https://doi.org/10.1111/14679604.12111

Education Review Office (ERO) (2010). Including students with high needs. Available from http://www.ero.govt.nz/publications/including-studentswith-high-needs/

Education Review Office (ERO) (2013). Including students with high needs in primary schools. Available from http://www.ero.govt.nz/publications/including-students-with-high-needsprimary-schools/

Education Review Office (ERO) (2015). Inclusive practices for students with special education needs in schools. Available from http://www.ero.govt.nz/assets/Uploads/Inclusive-practices-for-studentswith-special-needs-in-schools.pdf

Kearney, A. (2011). Exclusion from and within school. Issues and solutions. Rotterdam: Sense Publishers.

Kearney, A (2014). Parent-school relationships and exclusion from and within school. In R. Wills, M. Morton, M. McLean, M. Stephenson \& R. Slee (Eds.). Tales from school. Learning disability and state education after administrative reform (pp. 133-148). Rotterdam: Sense Publishers.

Lindqvist, G. (2013). Who should do what to whom? Occupational groups' views on special needs. School of Education and Communication, Jonkoping University. Dissertation Series 22. Available from: http://www.divaportal.org/smash/get/diva2:665062/FULLTEXT01.pdf

Mackenzie, S. (2007). A review of recent developments in the role of the SENCO in the UK. British Journal of Special Education, 34(4), 212-218. https://doi.org/10.1111/j.1467-8578.2007.00481.x

Ministry of Education (1996). Special Education 2000. Wellington, New Zealand: Author.

New Zealand Human Rights Commission. (2010). Human Rights in New Zealand. Nga Tika Tangata O Aotearoa. Wellington, New Zealand. Author. Available from https://www.hrc.co.nz/files/7014/2388/0544/Human Rights Review 201 0 Full.pdf

New Zealand Youthlaw. Tino Rangatiratanga Taitamariki (2012). Out of school, out of mind: The need for an independent education review tribunal. Wellington, New Zealand: Author. Available from http://www.youthlaw.co.nz/wp-content/uploads/Out-of-School-Out-ofMind-web1.pdf

New Zealand Educational Institute [NZEI]. (2016). Survey of Special Education Needs Coordinators (SENCO) 2016. Available from http://www.standupforkids.org.nz/wp-content/uploads//2012/08/SENCOreport-05feb2016.pdf

Organisation for Economic Co-operation and Development [OECD]. (2014). TALIS 2013 results: An international perspective on teaching and learning. OECD Publishing. http://dx.doi.org/10.1787/9789264196261-en

Oldham, J., \& Radford, J. (2011). Secondary SENCO leadership: A universal or specialist role? British Journal of Special Education, 38(3), 126-134. https://doi.org/ 10.1111/j.1467-8578.2011.00513.x

Rayner, S. (2007). Managing special and inclusive education. London, United Kingdom: Sage 
Slee, R. (2011). The irregular school. Exclusion, schooling and inclusive education. London, United Kingdom: Routledge.

Taylor, D. (2014). In-school factors associated with the SENCO role that influence the rate of referral to the RTLB service. Unpublished Masters Thesis. Massey University Palmerston North New Zealand Available from

https://mro.massey.ac.nz/bitstream/handle/10179/5723/02_whole.pdf?se quence $=2 \&$ isAllowed $=y$

Teacher Training Agency (TTA) (1998). National standards for special education needs coordinators. London, United Kingdom: TTA.

Winwood, J. (2016). Leading and managing for inclusion. In Z. Brown (Ed.), Inclusive education. Perspectives on pedagogy, policy and practice. (pp. 23-22). Abingdon, Oxford, United Kingdom: Routledge

Wills, R., \& Rosenbaum, S.A. (2014). The problematics of inclusive education in New Zealand today. In R. Wills, M. Morton, M. McLean, M.Stephenson \& R. Slee (Eds.), Tales from school. Learning disability and state education after administrative reform (pp. 91-108). Rotterdam, The Netherlands: Sense Publishers.

Wylie, C. (2000). Picking up the pieces: Review of Special Education 2000. Wellington, New Zealand: NZCER Press. Available from http://www.nzcer.org.nz/research/publications/picking-pieces-reviewspecial-education-2000 


\section{ABOUT THE AUTHOR(S)}

\section{ALISON CLAIRE KEARNEY Institute of Education Massey University}

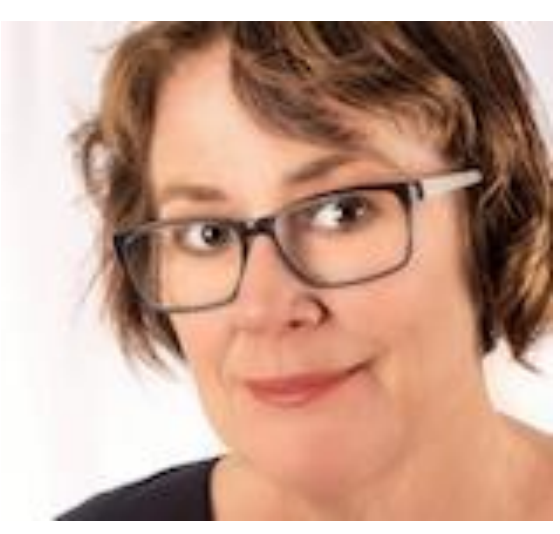

Alison Kearney is an Associate Professor in the Institute of Education at Massey University, New Zealand, where she coordinates the Masters of Education (Learning \& Teaching) Programme. She is co-director of the Equity through Education Research Centre and editor of the New Zealand educational journal, Kairaranga. Prior to taking up her position at Massey University, Alison was a primary school teacher. Her teaching and research interests include education for equity and inclusive education.

\section{MANDIA MENTIS} Institute of Education Massey University

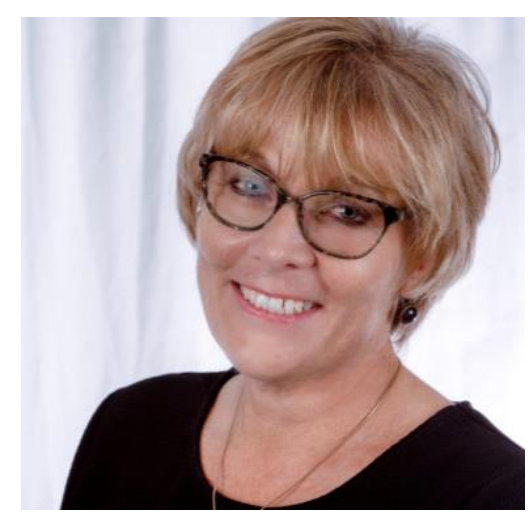

Mandia Mentis is an Associate Professor in the Institute of Education at Massey University, New Zealand. She coordinates the postgraduate Inclusive Education programme, is co-director of the Equity through Education Research Centre, and coordinates the national inter-professional programme for Specialist Resource Teachers. Her teaching and research interests include dynamic assessment, teaching for diversity, and the affordances of digital technologies to support life-long learning. 


\section{WENDY HOLLEY BOEN \\ Institute of Education \\ Massey University}

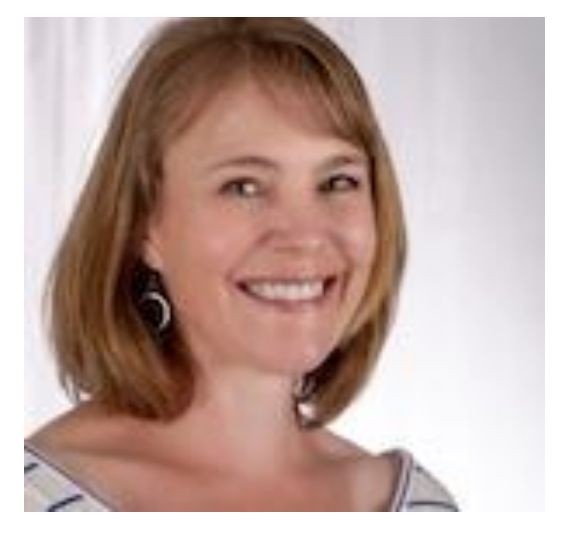

Wendy Holley-Boen lectures in the Institute of Education at Massey University, New Zealand. She is an Educational Psychologist and teaches across the Specialist Teaching areas of learning and behaviour as well inter-professional mentoring and supervision. She has recently completed her PhD in professional identity and wellbeing and developed a model of wellbeing for professionals that incorporates the three critical areas of stance, stamina and supports around professional practice. 